УАK 21

ББК 86.2

DOI 10.22394/1682-2358-2021-4-74-85

A.A. Kovalev, Candidate of Sciences (Politics), Associate Professor of the Department of State and Municipal Management of the NorthWest Institute of Management of the Russian Presidential Academy of $\mathrm{Na}$ tional Economy and Public Administration

\section{UNDERSTANDING THE PHENOMENON OF EVIL IN \\ CHRISTIANITY \\ AND ISLAM: \\ AN EXPERIENCE \\ OF HISTORICAL \\ AND PHILOSOPHICAL \\ COMPARISON \\ OF THE CONCEPTS \\ OF AL-FARABI, ANSELM AND THOMAS AQUINAS}

The treatment of the phenomenon of evil in Christianity and Islam on the example of philosophical heritage of Muslim theologian Al-Farabi and the pillars of Christian philosophy of Anselm of Canterbury and Thomas Aquinas is compared. It is proved that medieval philosophers sought to understand the problem of evil and how man should reconcile the existence of God with the existence of evil.

Key words and word-combinations: evil, good, Christianity, Islam, theodicy, Al-Farabi, Anselm of Canterbury, Thomas Aquinas.
A.A. КоһалеВ, кандидат политических наук, дочент кафедри государственного и муниципального управления Северо-Западного института управления Российской академии народного хозяйства и государственной службь при Президенте РФ (email:kovalev-aa@ranepa.ru)

\section{ОСМЫС АЕНИЕ ФЕНОМЕНА $3 \Lambda$ A}

В ХРИСТИАНСТВЕ И ИС $А$ АМЕ: ОПЫТ ИСТОРИКО-ФИАОСОФСКОГО СРАВНЕНИЯ КОНЦЕПЦИЙ ААЬ-ФАРАБИ, АНСЕ $\triangle \mathrm{ЬМА}$ И ФОМЫ АКВИНСКОГО

Аннотация. Сравниваются трактовки феномена зла в христианстве и исламе на примере философского наследия мусульманского богослова Аль-Фараби и столпов христианской философии Ансельма Кентерберийского и Фомы Аквинского. Приводятся позиции средневековых философов на то, как человек должен примирить существование Бога с существованием зла.

Ключевые слова и словосочетания: зло, добро, христианство, ислам, теодицея, Аль-Фараби, Ансельм Кентерберийский, Фома Аквинский.

B современную эпоху, когда поА угрозу поставлены важнейшие основания человеческого бытия, необычайно остро актуацизировацась проблема зиа, буквально заполонившего мир. Но старая арабская пословица недаром гласит: «З века, в том числе и в нашу эпоху, змо 
имеет много обличий, распознать которые порой необычайно трудно. Феномен зма часто становился объектом исследования ученых-гуманитариев - в первую очередь теологов и философов. Ответы на загадки вечной диалектической взаимосвязи добра и зма искали в богословии и истории философии как христианские, так и исламские теологи и религиозные философы. Их рассуждения могут помочь современному человечеству, заблудившемуся на экзистенциальных, этических и аксиологических дорогах нашего времени.

Специальных работ, исследующих трактовки феномена зма в среАневековой фимософии, немного. Тем более мало исследований, выполненных в русле историко-философской компаративистики. Хотя феномен зиа продуктивно изучался в работах отечественных и зарубежных ученых, таких как $\Lambda$. Антисере и $\Lambda$. Pеале [1], В.Т. Звиревич [2], М.Н. Коган [3], Аарс Свендсен [4], М.Е. Соболева [5], В.В. Соколов [6], в научном обиходе мало исследований, посвященных сравнению взглядов на природу зма, которые можно вычленить из наследия христианских и исламских мыслителей Средневековья. О философском наследии Аль-Фараби писали довольно интенсивно как отечественные [7-10], так и зарубежные ученые [11; 12], глубоко исследованы взгляды Ансельма [13; 14] и Фомы Аквинского [15-17], но сравнения воззрений этих мыслителей на природу зма не проводилось в отечественной научной митературе.

Цель Аанной публикации - сравнить трактовки феномена зма в христианстве и исламе на примере философского наследия мусульманского богослова Аль-Фараби и столпов христианской философии Ансельма Кентерберийского и Фомы Аквинского.

В истории философии были мыслители, которые синтезировали в своих размышлениях обсуждение свободы воли с анализом политической жизни, причем такой синтез предусматривац не просто обсуждение свободы в терминах определенной этической традиции, но и анализ проблемы зма, тесно связанной с теодицеей. Впрочем, основы дмя теодицеи можкно найти уже в неоплатонизме. В исламской культуре таким мыслителем был Аль-Фараби (872-950 гг.), полное имя которого Абу Наср МухаммеА ибн Мухаммед Аль-Фараби. Он считается отцом-основателем исламской философско-политической и этической мысли. В исламской культуре его именуют «вторым учителем», отводя роль первого Аристотелю. Этот мысмитель изучал наследие Пцатона и Аристотемя и оставил обширные комментарии к их трудам. Его теории политической жизни находились поА сильным влиянием идей идеального государства Пцатона.

Амя Аль-Фараби объяснить змо бымо просто. Смедуя интемлектуамьной традиции христианства, сформировавшейся посме работ Августина 
Блажкенного (354-430 гг.), созданных более чем за два столетия до возникновения ислама, он полагал, что змо проистекает из неверных и ошибочных человеческих поступков, осознанных и добровольных действий Аюдей, приводящих в конце концов к зАу. Выражая свою свободу, мюди имеют возможность выбирать, как они будут управлять собой и относиться к Аругим АюАям, и при этом неизбежкно, что некоторые буАут сознательно стремиться причинить страдания Аругим. Аیя А^ь-Фараби эта человеческая способность действовать именно таким образом является очевидным фактом.

ОАнако существуют альтернативы для этого. Аль-Фараби рассуждает о добродетелях души, таких как самоограничение. Эти способности служат противодействию нашим склонностям ко зцу. Стремление чемовека заставить других июдей страдать или даже увеличивать их страАания Аль-Фараби предмагает увязать с проблемой стабильности госуАарства, ибо деструктивные желания индивидов могут в совокупности подорвать и разрушить целостность социума. Тогда индивидуальное зАо перерастает в социальное, победить которое значительно сложнее.

Если бы каждый гражданин в государстве стремияся причинять страдания Аругим, то государство быстро скатилось бы в хаос и прекратило свое существование. Чтобы предотвратить эту катастрофу, Аль-Фараби предлагает научиться контролировать свои жекания и подсознательные импульсы и думать в терминах взаимосвязи между цюдьми, а не существующих межАу ними размичий. Апемлируя скорее к сходству межАу индивиАами, чем к существующим объективно различиям, Аль-Фараби размышияет о зле и его связи с политикой, акџентируя внимание на общей обязанности всего человечества сохранить жизнь и благоговеть переА ней.

Аля Аль-Фараби именно наши осознанные добровольные действия определяют то, кем мы являемся. Человек, избравший самоограничение и умеренность, неизменно будет вести добродетельную жизнь. Аобродетельная жкизнь укрепляет государство, тогда как стремление причинить вреА Аругим и увеличить их страдания ведет к зАу и окончательному разрушению государства и общества.

В рамках своей политической философии Аль-Фараби обсуждает природу зма и характеризует два его типа [18] . В своей характеристике зца Аль-Фараби во многом предшествовац дискурсу Святого Ансельма о проблеме зма [19] . Илеи Аль-Фараби выступают как бы связующим звеном межАу Августином Блажкенным и преАставителями схоластики [20].

В своих политических трудах Аль-Фараби высказывает следующее преАположение: «ЗАо вообще не существует ни в оАном из этих миров и вообше в той реальности, чье сушествование не обусловлено человеческой волей... Это потому, что змо бывает Авух видов. ОАно - это

76 Bulletin of the Volga Region Institute of Administration 2021. Vol. 21. № 4 
страдание, противоположное счастью. А второе - это все то, посредством чего достигается страдание. Несчастье есть зло в том смысле, что оно представляет результат, к которому человек приходит, сам не со-

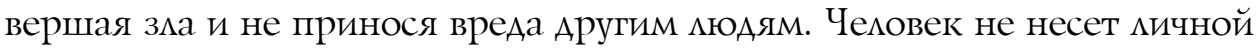
ответственности за такое зцо. Второе - это добровольные и осознанные Аействия Аюдей, которые приводят к зАу и несчастью».

Аль-Фараби четко определяет существование двух форм зма, обе из которых описываются в терминах человеческого страдания, которое он рассматривает как конечную цель зма. При анализе зма размичие в типологии не отражает различия в телеологии, поскольку несчастье явмяется целью Аля обоих типов зма. Размичия в типах зма, однако, отражают разцичия в природе их существования. Аیя Аль-Фараби одна форма зма является результатом «несчастья, противоположного счастью», а Аругая - результатом "добровольных действий, которые ведут к несчастью» [21]. Что касается отношения межАу змом и свободной волей, то важно отметить, что свободная воля, то есть «добровольные Аействия» человека, объясняют только второй тип зца.

Относительно определения преАрасположенности человека ко зиу, продолжает Аль-Фараби, «вряд ми можно найти человека, наделенного с самого начаца таким совершенством, что в нем вообще не обнаруживается никакого несоответствия и что остальные его действия, его образ жизни и его моральные привычки находятся в соответствии с справеАливостью и равенством, не склоняясь ни к оАной из крайностей или к господству оАних противоположностей наА Аругими» [22].

Аля Аль-Фараби змом является такой результат наших добровольных действий, который приводит к страданию. Конечно, наше несовершенство как греховных человеческих существ может всегда привести к ошибочному мышлению, которое, в свою очередь, приведет к страданию, но наши действия должны управляться добродетелью. Аобродетельный человек будет избегать зма и принимать добро, и будет Аостоянием городского сообщества, тогда как человек без добродетели будет осознанно и даже не без удовольствия принимать зцо, а потому он должен быть изгнан из города. Аль-Фараби пишет: «ЗАо прекраша-

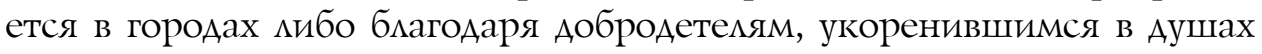


можкет быть прекрашено добродетелью, утвердившейся в его Ауше, или самоограничением, Аолжен быть изгнан за городские пределы» [23] .

Аля Аль-Фараби змо угрожкает стабильности города и, следовательно, всего государства. Если мы хотим защитить государство, то АОлжны стремиться привить добродетель в жизнь каждого гражАанина; в противном случае змо будет распространяться, уничтожая насемение и не- 
избежно дестабилизируя государство. Таким образом, Аля Аль-Фараби зАо определяется в терминах страдания, которое явцяется результатом Аобровольного действия мюдей. Поскольку законы принимаются правительственными чиновниками Аля защиты жизни и благополучия своих граждан, то существование зцокачественных сил внутри населения, стремящихся к распространению нищеты, подрывает способность государства защищать свой народ, что оправдывает утверждение А^ь-Фараби о том, что «мюбое человеческое существо, чье змо не может быть приостановлено... Аолжно быть изгнано за городские предемы» [24] .

Аля Аль-Фараби змо исходит из Авух источников, и Аюбой из этих источников может также развратить тех, кому поручено охранять жизнь граждан. Его конџепция четко определена и сформулирована. ОАнако, несмотря на различия в типологии, телеология остается той же самой, и ее целью является исключение возможностей дмя реализации зма. Если цель правителя состоит в том, чтобы исключить возможность выигрыша оппозиционеров, могущих нанести змо государству, $и ш и в ~$ их прав или ограничив доступ к различным благам, то, делая добро государству, власть непосредственно участвует в обострении страданий тех, кто оказался в состоянии изгоев, подвергшись остракизму. БАаго

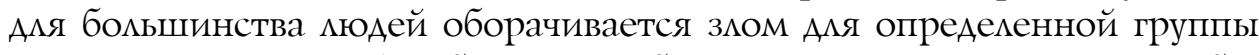
подАанных. Но такой выбор между большим и меньшим змом неизбежен, такова Аиалектика политической жизни.

С точки зрения исламской концепции зма, действия правительства в равной степени заслуживают порицания. Согласно исламскому коАексу, как приверженец опредеменной морали, так и те, кому поручено управмять населением, обязаны совершать надлежащие морамьные действия. Аюбое намерение, озвученное или нет, записанное или даже мысленное, направленное на то, чтобы вызвать или продиить страдания Аругого человека, считается зцом.

Если Аль-Фараби использовал в своем учении мысли и достижения неоплатоников и Августина Блажкенного, то католический богослов, средневековый философ Ансельм Кентерберийский (1033-1109 гг.) из итальянского города Аосты продолжиц эту интемлектуальную традицию. Видимо, ему были известны труды не только отцов христианской церкви, но и работы исламских богословов, в том числе и Аль-Фараби. Ансельм рассматривац веру как основу рационального знания, а первородный грех - как преступление против Божественного миропорядка. Этот мыслитель доказательно и красиво представил в трактате «Почему Бог стал человеком» суть христианского учения об искуплении в юридической терминологии. Проистекающие из первородного греха зАые поступки человека являются преступцением против Божьего мира [25] . 
Ансельм продолжкает дискуссию о зле: «Аавайте теперь обратимся к рассмотрению воли и вспомним вывоА, к которому мы пришии: а именно, что воця к счастью, какой бы она ни была, не явцяется злом, но будет добром до полного достижкения справедливости. Из чего слеАует, что, когда она отказывается от полученной справедливости, если она явмяется той же сущностью, что и прежде, она есть нечто хорошее, поскольку она существует, но поскольку справедиивости нет в том, в чем она была, она называется змой и несправедливой» [26].

Ансельм возвращается к платоновской концепции справедливости и Аалее продолжает размышиять наА взаимосвязью между тем, что справедливо, и тем, что хорошо. Концепция справедливости в политическом смысле не нова дия Ансельма; это концепция, по сути, такая же Аревняя, как и сама западная философия. ОАнако Ансельм Кентерберийский смог внести свой вклаА в объединение понятий справедливости и несправеАливости с конџепџиями добра и зма.

Внимательный анализ цитаты Ансельма Кентерберийского показывает, что преднамеренная попытка устранить справедливость из моральных соображкений является одновременно «змой и несправедливой». Если, определяя нравственность какого- иббо действия, носитель морали умышленно устраняет или упускает из виду понятия справеАмивости и равенства с целью исключения определенных членов сообщества из круга индивидов, защищаемых господствующими моралью и правом, то такое действие носителя морали должно рассматриваться, согласно Ансельму, как злое и несправедливое. Что важно понять из формулировки зла Ансельмом, так это тот акцент, который он делает на воле человека и на осуществлении его свободы в осознанном выборе собственных действий. ЗАесь он не выходит за рамки аргументов, сформулированных еще Августином Блажкенным.

Различие в аргументах между представлениями Ансельма и Августина о природе воли может показаться не таким значительным, но все же это - существенное размичие. Аля Августина мы свободны опреАелять свои поступки, а змо - это отсутствие добра, что справеАливо и для Ансельма. Разница, однако, в том, что дия Ансельма «природа, в которой обнаруживается несправеАливость, есть нечто змое, потому что она есть нечто реальное и отличается от несправедиивости, которая есть зио и ничто. Следовательно, то, что реально, создано Богом и исхоАит от него; то, что есть ничто, то есть зАо, которое также исходит от Бога, который виновен в этом» [27]. Августин вообще не усматривац ни в природе, ни в Боге зла, хотя понимац, что даже Аюцифер как ангем явмяется творением Бога. Впоследствии мысли о «темной основе» Бога продуктивно разовьет Ф.В.Й. Шемиинг [28] . 
Аргумент Ансельма здесь немного сложкен и, возможно, запутан, но важно понять его смысл. Обстоятельства, в которых мы идентифицируем действие или событие как несправедливое, сами по себе являются примером зла, то есть конкретное событие реального мира, в котором происходит зАодеяние, явмяется идентифиџируемым примером зАа. Это отождествление зАого события, однако, отличается от простого отсутствия добра, которое также явцяется зцом, но не преАполагает никакого идентифицируемого существования. Оно - змо постольку, поскольку оно не есть добро, но оно не отождествцяется с никаким материальным, физическим, действительным змом. Позже он пишет: «КогАа мы слышим слово «зАо», мы не боимся зАа, которое есть ничто, но того, что есть нечто реальное и следует за отсутствием добра. Многие страдания следуют за несправедиивостью и нравственной слепотой, и они на самом деле ничто, но эти страдания - змо и нечто реальное, и именно их мы боимся, когда слышим слово «змо» [29] .

У Ансельма Кентерберийского есть две радикально размичные концепции зла; есть то, что мы назовем концепцией «зАа как ничто» и «зАа как нечто». Приведем два аргумента. Во-первых, понятие «змо как ничто» явцяется синонимом того, что просто не явцяется Аобром, и, во-вторых, мы допускаем двусмысленность в использовании термина «зло», если мы взаимозаменяемо используем понятие «зло» как то, что не явмяется добром (зАо как ничто), с одной стороны, и змо как реальный акт насилия и разрушения, с Аругой. Эти два понятия не взаимозаменяемы.

Размышления Ансельма о различии межАу «злом как ничто» и «змом как нечто» и обсуждение Аль-Фараби двух форм зла явмяются важным вкладом в философское исследование феномена зиа. Мы часто уклоняемся от употребления термина «змо», существование которого Ансельм признавал и которое слишком многие упускали из виду. Мы не используем термин «зло» в том же смысле, если мы определяем событие, которое не было Аобром, из чьих-то добровольных действий, которые привели к злу, имеющему чисто семантическое, а не онтологическое значение.

И Аль-Фараби, и Ансельм Кентерберийский обсуждают феномен зца, рассматривая зАо, возникающее в противоположность тому, что есть добро, и змо, возникающее из осознанных действий человека. Если добровольное действие основано на свободе воли, а воля является источником существования зАа, то добровольное действие явмяется источником существования зма.

Как известно, Святой Фома Аквинский (1225-1274 гг.) преАложии всесторонний анализ зма в своем великом труде «Сумма теологии». Его анализ учитывал достижения предшествуюшей религиозной философии, прежде всего выводы Августина. Святой Аквинат в конечном счете не 
согласен с концепцией, что высшее змо можкет существовать, но он выАвигает следующий аргумент: «Аалее, если одна противоположность есть в природе, то и другая тоже. Но высшее благо находится в природе и явмяется причиной всякого блага... Поэтому и существует высшее зло, противостоящее ему как причина всякого зАа. Аалее, как мы находим Аобро и кучшее, так мы находим змо и худшее. Но Аобро и кучшее рассматриваются по отношению к еще более лучшему. Поэтому зло и хуАшее рассматриваются по отношению к какому-то высшему зму» [30] .

Формулируя свое reductio ad absurdum (доведение до абсурда), Фома Аквинский гипотетически преАположиц, что можно утвержАать о существовании высшего зма, основываясь на конџепџии высшего блага (summum bonum). Поскольку природа состоит из противоположных сущностей, и высшее благо существует в природе, кажется могичным заключить, что высшее змо (summum malum) также существует. Если бы высшее змо сушествовало, оно было бы причиной всех сушествующих зол. Фома Аквинский рассматривает возможность его существования, но опровергает бесконечный регресс причин и следствий, который был бы результатом отсутствия высшего зма. Он пишет: «Аацее, зАо слеАствия сводится к зАу причины, потому что несовершенное следствие происходит от несовершенной причины... Но в этом вопросе мы не можем иАти до бесконечности. Поэтому мы должны преАполагать одно первое зАо как причину всякого зАа» [31] .

ПреАполагая цогическую необходимость высшего зиа, которое предотвращает регрессию причин и следствий до бесконечности, Аквинат убедительно возражает против возможности его существования, апе -

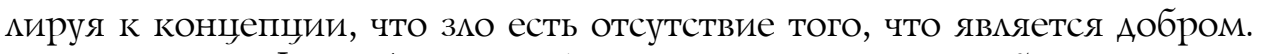
Тем не менее Фома Аквинский пишет: «Но не может быть высшего зца, потому что... хотя змо всегда уменьшает добро, оно никогда не поглощает его полностью; и таким образом, поскольку хорошее всегда остается, ничто не может быть совершенно плохим» [32].

Фома Аквинский приходит к выводу, что высшее зАо не может существовать, потому что оно уничтожило бы себя. Кроме того, Фома Аквинский должен отвергнуть эту концепцию высшего зма, потому что существование всемогушей симы зла еще больше обострило бы проблему зла и особенно подорвало бы мюбовь к Богу и веру в Него. Бог - создатель Вселенной, и невозможно было бы объяснить сушествование абсомютного зца, которое является причиной всех незначительных случаев его воплощения. Таким образом, теологически Фома Аквинский не может подАержать понятие высшего зла, потому что тогда ему пришиось бы решать труднейшую задачу объяснения его сушествования в свете характеристик бкагостного Бога. На этих основаниях и на основании 
своих религиозных убежлений Фома Аквинский должен был отрицать существование высшего зАа. Поэтому говорят, что змо приближается к высшему зцу, но оно не способно полностью уничтожкить то, что является добром, поскольку змо опредемяется как простое отсутствие добра. Если существование зла неразрывно связано с добром и более правильно определяется как отсутствие добра, то полное отсутствие добра служило бы достаточным условием Аля уничтожкения зма.

Что такое змо, Аолжно быть известно из анациза понятия добра. Аобро есть все желаемое, следовательно, так как каждая природа жемает своего собственного бытия и своего собственного совершенства, то бытие и совершенство мюбой природы имеет характер благости. Таким образом, не может быть, чтобы змо означало бытие ици какуюмибо форму природы, поэтому поА именем зАа подразумевается просто отсутствие добра. И это то, что подразумевается, говоря, что «зАо не есть ни сущность, ни добро. Ибо поскольку бытие как таковое есть бцаго, то отнятие одного подразумевает отнятие Аругого».

Аквинат преАполагает, что бытие имеет "характер благости», то есть утверждает, что то, что существует (бытие), есть благость, то есть вся действительность есть благость. Таким образом, добро есть означающее, и оно означает бытие. Что интересно в утверждении Аквината, хотя он и не акцентирует на этом внимание, так это то, что зцо не явцяется и не может быть означающим, то есть змо не означает бытия. На самом деле, если кто-то определяет зло как недостаток добра (а недостаток преАставляет собой отсутствие в Аолжной мере), если означающее $\Lambda и$ шено определенных свойств, тогда то, что оно означает, также Аолжно быть мишено их. Это отражено в утверждении Фомы, что «недостаток одного подразумевает недостаток Аругого». Недостаток бцагости есть недостаток бытия, его несовершенства (того, что обозначается благостью). Таким образом, если принять предпосылку, что зло определяется как недостаток добра и что добро означает бытие, то следует признать, что неверно закмючать, что зцо также означает бытие. Значение бытия не может быть выявлено на этих основаниях как простое отсутствие добра, так как отсутствие, недостаток не имеют никакого значения [33].

Бытие обозначается благостью, без которой оно перестало бы существовать. Так как змо не может означать бытие, мы осознаем существование зма из-за недостатка добра. Без добра бытие перестало бы быть, то есть перестало бы существовать, так как оно обозначается и понимается через добро. Таким образом, аргументация в пользу возможности высшего зма требует отсутствия добра, а добро есть единственный источник значения бытия. Высшее змо устраняет значение бытия как благости и тем самым само бытие. На этом основании высшее змо невозможно, так как оно приводит к полному уничтожению бытия. 
Фома Аквинский вводит понятие высшего зма толыко для того, чтобы в конце конџов доказать онтологическую невозможность его существования. ОАнако возникает вопрос, почему Фома Аквинский отрицает онтологию высшего зма? Отрицая онтологическое существование высшего зма, Фома Аквинский сохраняет монотеистическое чувство Всеблагого Бога. Богословие Фомы Аквинского стало основой его философии, согласно которой он не мог допустить существования высшего зма, поскольку такое признание подорвало бы его теологические убеждения. Здесь он следовал не только Августину Блаженному и прочим преАставителям патристики, но и интемлектуальной традиџии Аль-Фараби.

Если попытаться конџептуализировать онтологическое существование высшего зма со светских позиций, то рождаются две кмючевые идеи. Во-первых, формулируя онтологию высшего зма, можно утвержАать, что его реальность не явцяется результатом континуума, в котором абсолютное зАо доминирует наА всем существованием.

Можно, конечно, утверждать, что онтология высшего зАа возникает как мимолетное явление, которое устремляется на поверхность, разрушает все на своем пути, а затем рушится под грузом собственной гнусности. В мировой истории высшее зАо проявцяется как полное опустошение сил народов и государств, истошение пассионарности, если вспомнить термины $\Lambda . Н$. Гумилева [34] .

Во-вторых, онтологическая основа высшего зла может быть обоснована в контексте непреклонной попытки зма уничтожить человеческую жизнь. В отличие от проблемы, с которой столкнулся Фома Аквинский при описании трансцендентного, то есть сверхъестественного зАа, светский гуманист, конечно, может объяснить онтологию зма, не обращаясь также к трансцендентности феномена зма. Таким образом, высшее змо онтологически обосновано, если его проявление отнесено к этому миру. В то время как теист может представить проявление высшего зАа как окончательную победу Аьявола наА силой добра, светский гуманист может предложить более прагматичный отчет о его проявмении в геноциде и массовом истреблении мюдей. НеАаром итальянский поэт и прозаик Примо Аеви, происходивший из семьи пьемонтских евреев и переживший ужасы наџистского конџлагеря, писал: «Если есть Освенцим, то Бога нет» [35, p. 181] .

Онтологическая невозможность высшего зма вытекает только из принятия теистической космогонии. Если принять натурацистическую космогонию Вселенной, то онтологическую возможность высшего зАа можно объяснить как тотальную попытку самой природы уничтожить человеческую жизнь.

Подведем итоги. Средневековые философы всеми силами стремились 
понять проблему зла и то, как человек, особенно человек веры, должен примирить существование Бога с существованием зма, но их решения проблемы зла проявлялись в широком спектре альтернативных объяснений. Независимо от того, рассматривался ми Бог как отсутствующее, не

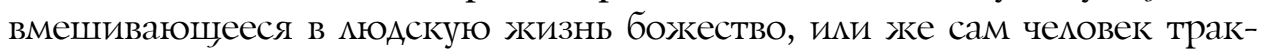
товался как источник зла, возникающего в процессе осуществления свободы, на протяжении всего Средневековья обсуждение зма всегда формулировалось в контексте проблемы зма. Проблема зла, однако, является проблемой только Аля теиста, что заставицо многих деистов и атеистов рассматривать исследование природы зма как по существу бесплодное.

Воззрения Аль-Фараби, Ансельма и Фомы Аквинского восходят к учению Августина Блажкенного о природе зма и - при наличии существенных разцичий - генетически связаны с ним. ИАеи Аль-Фараби выступают как бы связующим звеном между Августином Блаженным и представителями схоластики. И Аль-Фараби, и Ансельм Кентерберийский обсуждают феномен зма, рассматривая змо, возникаюшее в противоположность тому, что есть добро, и зАо, возникающее из осознанных действий человека. Если добровольное действие основано на свободе воли, а воля явцяется источником существования зма, то Аобровольное Аействие явцяется источником сушествования зма.

Богословие Фомы Аквинского стало основой его философии, согласно которой он не мог допустить сушествования высшего зма, поскольку такое признание подорвало бы его теологические убеждения. 3Аесь он следовац не только Августину Блаженному и прочим представителям патристики, но и интемлектуальной традиции Аль-Фараби.

Теодицея как оправдание Бога стала довольно популярным занятием в истории европейского мюбомудрия - начиная со СреАних веков и вплоть до Готфрида Аейбниџа - автора самого термина и знаменитого труда. Наличие в мире зма объяснялось недостатком блага, конечностью сотворенного сушего. БАаго в мире проистекает от Бога, а зио рассматривалось как недостаток или отсутствие блага и самого бытия - как «не-сущее. Мы в современную эпоху не можем целиком и полностью принять такие трактовки феномена зма и скмонны, скорее, примириться с реальностью и неизбежностью зма и бороться с ним по мере наших сил и возможностей.

\section{Библиографический список}

1. Антисере Д., Реале Дж. Западная философия от истоков до наших дней. Античность. Средневековье. СПб., 2003.

2. Звиревич В.Т. Философия древнего мира и средних веков. М., 2002.

3. Коган Л.Н. Зло. Екатеринбург, 1992. 
4. Свендсен Л. Философия зла. М., 2008.

5. Соболева М.Е. Логика зла. СПб., 2015.

6. Соколов В.В. Средневековая философия. М., 2001.

7. Ардакани Р.Д. Фараби - основоположник исламской философии. М., 2014.

8. Гафуров Б. Г., Касымжанов А.Х. Аль-Фараби в истории культуры. М., 1975.

9. Хайруллаев М.М. Абу Наср аль-Фараби: 873-950. М., 1982.

10. Туманян Т.Г., Держивицкий Е.В. Теория воспитания Платона в политической философии Аль-Фараби // Политика и образование. СПб., 2008. С. 135-148.

11. Habib Hassan Touma. The Music of the Arabs. Trans. Laurie Schwartz. Portland (Oregon): Amadeus Press, 1996.

12. Fakhry M. Al-Farabi, Founder of islamic neoplatonism: His life, works, and influence. Oxford: Oneworld Publications, 2002.

13. Давыденков О.В. Догматическое Богословие. М., 2013.

14. Klaus von Stosch. GrцЯer als am GrцЯten? Untersuchungen zum Gottesbegriff Anselms von Canterbury // Theologische Zeitschrift. 2006. № 62. S. 420-432.

15. Бандуровский К.В. Проблемы этики в «Сумме теологии» Фомы Аквинского // Вопросы философии, 1997. № 9. С. 156-162.

16. Боргош Ю. Фома Аквинский. М., 1966.

17. Гертых В. Свобода и моральный закон у Фомы Аквинского // Вопросы философии. 1994. № 1. С. 87-101.

18. Ian Richard Netton. Al-Farabi and His School. Routledge, 2005.

19. Ансельм. Сочинения. М., 1995.

20. Азимхан А. Философское приношение Абу Насра аль-Фараби. Алматы, 2006.

21. Бурабаев М.С., Жлмухамедова Н.Х., Кенисарин А.М. Духовное наследие АльФараби: история и современность. Алматы, 2001.

22. Касымжанов А.Х. Абу-Наср аль-Фараби. М., 1982.

23. Lameer J. Al-Farabi and Aristotelian syllogistics: Greek theory and Islamic practice. Brill, 1994.

24. Аль-Фараби А.Н.М. Философские трактаты. Алма-Ата, 1970.

25. Davies B., Leftow B. The Cambridge companions to Anselm. Cambridge: Cambridge univ. press, 2004.

26. Saint Anselm. Anselm of Canterbury: The Major Works. Oxford University Press, 1998.

27. Saint Anselm. Anselm's Philosophy. Lulu.com, 2016.

28. Шеллинг Ф.В.Й. Сочинения: в 2 т. М., 1987.

29. Saint Anselm. Monologium. CreateSpace Independent Publishing Platform, 2015.

30. Фома Аквинский. Сумма теологии. СПб., 2007.

31. Фома Аквинский. Сочинения. М., 2002.

32. Фома Аквинский. Онтология и теория познания: (Фрагм. соч.). М., 2001.

33. Фома Аквинский. Учение о душе. СПб., 2004.

34. Гумилев Л.Н. От Руси до России: очерки этнической истории. М., 2014.

35. Anissimov M. Primo Levi ou la tragŭdie d'un optimiste: biographie. Paris: Lattus, 1996. 